\title{
Reproducibility of and Correspondence among Different Hepcidin Forms in Blood and Urine and Their Relationships to Iron Status in Healthy, Male Guatemalan Volunteers Observed over 9 Weeks
}

\author{
Klaus Schuemann ${ }^{a} \quad$ Noel W. Solomons ${ }^{b}$ Coby M. Laarakkers ${ }^{c}$ \\ María-Eugenia Romero-Abal $^{\mathrm{b}}$ Sylvia Kroll ${ }^{\mathrm{a}}$ Guenter Weiss $^{\mathrm{d}}$ \\ Dorine W. Swinkelsc

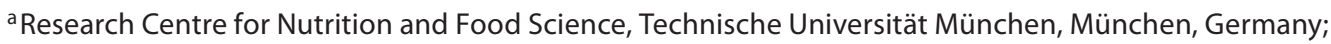 \\ ${ }^{\mathrm{b}}$ Centre for Studies in Sensory Impairment, Aging and Metabolism, Guatemala City, Guatemala; ' Department of \\ Laboratory Medicine and Hepcidinanalysis.com, Radboud University, Nijmegen, The Netherlands; ${ }^{\mathrm{d}}$ Department of \\ Internal Medicine I, Clinical Immunology and Infectious Diseases, Medical University Innsbruck, Innsbruck, Austria
}

\section{Key Words}

Hepcidin-25 • Prohepcidin · Ferritin • Iron status •

Iron regulation $\cdot$ Guatemala

\begin{abstract}
Background/Aims: Prohepcidin and the active form hepcidin-25 are two variants of the peptide hormone hepcidin for iron homoeostasis. Their regulatory role and usefulness as biomarkers of the iron status are uncertain. Our aim is to describe the intra-individual variance of serum and urinary hepcidin- 25 and prohepcidin concentrations, the mutual associations of the 4 hepcidin formats, and their correspondence with iron status variables in male Guatemalan volunteers. Methods: Eight healthy adult males provided serial samples of serum and urine without previous iron dosing over 6 intervals during a 9-week protocol period. Prohepcidin was assayed by a commercial enzyme immunoassay, and hepcidin-25 species in serum and urine were analysed by time-of-flight mass spectrometry after prior enrichment procedures. Results: Serum hepcidin-25 levels correlat-
\end{abstract}

ed significantly with urinary hepcidin-25 concentrations, whereas serum and urinary prohepcidin were not associated with one another or with the homologous or converse formats for hepcidin-25. Serum ferritin and transferrin saturation were significantly correlated with serum hepcidin-25 concentrations, but not with urine hepcidin- 25 or with either format of prohepcidin. Conclusion: Hepcidin-25 shows correspondence across biological fluids, and the background 'status' of hepcidin activation may be related to the host's iron stores, whereas prohepcidin concentrations showed no promise in this regard.

Copyright $\odot 2011$ S. Karger AG, Basel

\section{Introduction}

Throughout the history of clinical chemistry, when analysts develop an assay to detect and quantify a variable of biological relevance, the investigation of its concentration in human biological fluids and tissues follows shortly thereafter. Hepcidin was first described in 2001

\section{KARGER}

Fax +4161306 1234 E-Mail karger@karger.ch www.karger.com
(C) 2011 S. Karger AG, Basel

0250-6807/11/0582-0158\$38.00/0

Accessible online at:

www.karger.com/anm
Klaus Schuemann

Research Centre for Nutrition and Food Science

Technische Universität München

DE-85350 Freising (Germany)

Tel. +49 816171 3400, E-Mail k.schuemann@lrz.uni.münchen.de 
[1-3]. Since then, literature on hepcidin expanded exponentially, and the references given here and below are not meant to be exhaustive. Hepcidin is a peptide hormone that exists in various chemical forms. It has a precursor entity (prohepcidin) of an 84-amino acid chain length synthesized primarily in the liver. Prohepcidin analysis in human samples was described by Kulaksiz et al. [4] and was systematically applied in urine $[5,6]$ and serum/plasma [5-9]. Some workers found physiologically expected responses $[6,8,10]$, whereas others did not $[5,7,11,12]$, leaving questions regarding the true identity and metabolic and regulatory role of prohepcidin unanswered. The active form of hepcidin has 25 amino acid residues (hepcidin-25); it can be analysed both in the circulation [13-25] and the urine [13, 26-39], either as hepcidin-25 $[4,13,16,23,24]$ or along with other isoforms (hepcidin-20 and hepcidin-22) [18, 20-22]. An assay adapted to determine hepcidin-25 has been specifically developed in one of our laboratories (D.W.S.) [14] and was used in this study.

The present report is part of a central study that compares changes in serum iron and non-transferrin-bound iron after weekly ingestion of oral iron preparations at 6 increasing single dose levels $(0,15,30,60,120$ and $240 \mathrm{mg}$ $\mathrm{Fe}$ ) given over a period of 9 weeks at weekly intervals (14 days after the 2 highest dosages). This data analysis restricts itself to basal samples collected without iron ingestion and permits repeated intra-individual comparison of all 4 hepcidin formats - prohepcidin and hepcidin-25, each in serum and urine - in healthy human subjects in a developing country environment. It includes the meticulous characterization of individual iron status (haemoglobin, ferritin, transferrin saturation) and the state of inflammatory reactivity (white blood count and cytokines) in the context of the central study, with the goal to check in principle if any of the urinary hepcidin species may serve as a non-invasive variable to assess body iron status in developing countries.

\section{Subjects and Methods}

\section{Subjects}

A group of 8 healthy Guatemalan males, aged between 19 and 54 years, were enrolled in the study. None of them reported any history of chronic or acute diseases, or consumption of nutritional supplements during the previous 6 months. The Human Subjects Committee of the Center for Studies of Sensory Impairment, Aging and Metabolism approved the protocol. Subjects signed written informed consent and were compensated for their participation.

Prohepcidin and Hepcidin-25 Correlates

as Biomarkers in Healthy Men

\section{Study Design}

This paper uses and reports only the values obtained in the first morning (fasting) specimen of serum or urine. The fasting data set supplies up to 7 values per subject or up to 56 values per group analysis, except where missing fasting values might have occurred. Occasionally, additional samples were drafted for confirmation as described in the text.

\section{Sample Collection Procedures}

Five millilitres of venous blood were sampled in the morning in a fasting state prior to administration of ferrous sulphate syrup (Fer-In-Sol ${ }^{\circledR}$, Mead Johnson, Evansville, Ind., USA). In the placebo group, all 4 samples were included in the analysis, i.e. 1 sample obtained before and 3 samples collected after intake of plain water. Serum was obtained after clotting and centrifugation at $3,000 \mathrm{rpm}$ for $5 \mathrm{~min}$, then frozen in aliquots at $-20^{\circ} \mathrm{C}$. First morning urines were collected at home, brought to the laboratory on ice, aliquoted and stored on dry ice after addition of phenylmethansulfonylfluorid (1 $\mu$ l PMSF/ml urine; Sigma, Munich, Germany). No alcoholic beverages were permitted during the $24 \mathrm{~h}$ before each study day, and smoking was not allowed on blood extraction days.

\section{Laboratory Assays}

Iron Status Parameters. Haemoglobin concentration, leucocytes and packed cell volume were determined in Guatemala City at baseline and at the end of the study in an automated haematological profile analyser (Cell-Ruby, Ruby ${ }^{\mathrm{TM}}$, Abbott Diagnostics, Santa Clara, Calif., USA). Serum ferritin and transferrin were determined from frozen samples by turbimetric tests (Roche, Mannheim, Germany), and serum iron concentration was measured by a ferrozine-based assay (Roche). Transferrin saturation was calculated from serum transferrin and serum iron concentrations.

Inflammatory and Oxidative Markers in Serum and Urine. Interleukin- 4 and tumour necrosis factor- $\alpha$ concentrations, reflecting serum levels of critical anti-inflammatory and pro-inflammatory cytokines, were quantified in the serum by use of the Quantikine ${ }^{\circledR}$ Immunoassays (R\&D Systems, Wiesbaden, Germany).

Determination of Hepcidin Forms. Prohepcidin concentrations in serum and urine were determined by an enzyme immunoassay kit (DRG Instruments $\mathrm{GmbH}$, Germany). Urinary hepcidin-25 was semi-quantified as described earlier [13]. Serum hepcidin-25 was measured by use of matrix-assisted laser desorption/ ionization time-of-flight mass spectrometry (MALDI-TOF MS) performed by an updated form of our previously described method $[13,14]$. For the quantification of hepcidin in serum, an internal standard (synthetic hepcidin-24, Peptide International Inc., Louisville, Ky., USA) was added to $100 \mu$ l urine and $50 \mu \mathrm{l}$ serum before total hepcidin was isolated from the sample with MacroPrep ${ }^{\circledR}$ CM Support beads (Bio-Rad Laboratories, Hercules, Calif., USA) as described by Park et al. [2]. Next, hepcidin was applied to an MSP 96 polished-steel MALDI target plate followed by the addition of energy absorbing matrix, $5 \mathrm{mg} \alpha$-cyano-4-hydroxy-cin-

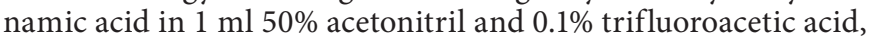
all in nitrogen atmosphere. Mass-to-charge $(\mathrm{m} / \mathrm{z})$ spectra were generated using MALDI-TOF MS (Microflex LT, Bruker Daltonics $\mathrm{GmbH}$, Bremen, Germany) in positive, linear ion mode and 500 laser shots (initial laser power 60\%, laser attenuator offset $25 \%$ and range 20\%). Pulsed ion extraction was set to $150 \mathrm{~ns}$. 
Table 1. Demographic characteristics, nutritional and haematological status and inflammatory markers in 8 adult volunteers (subjects A-H)

\begin{tabular}{|c|c|c|c|c|c|c|c|c|c|c|c|}
\hline Variables & A & B & $\mathrm{C}$ & $\mathrm{D}$ & $\mathrm{E}$ & $\mathrm{F}$ & G & $\mathrm{H}$ & Mean & $\mathrm{SD}$ & Median \\
\hline Age $^{1}$, years & 25 & 42 & 19 & 35 & 33 & 54 & 33 & 28 & 34 & 10 & 33 \\
\hline $\mathrm{BMI}^{1}$ & 19.4 & 19.6 & 20.0 & 20.0 & 21.9 & 24.7 & 27.4 & 22.0 & 21.9 & 2.7 & 21.0 \\
\hline Haemoglobin $^{1}, \mathrm{~g} / \mathrm{dl}$ & 14.9 & 14.3 & 17.6 & 15.6 & 15.8 & 15.3 & 15.8 & 15.8 & 15.6 & 0.9 & 15.7 \\
\hline Ferritin $^{2}, \mu \mathrm{g} / \mathrm{l}$ & $56(19)$ & $276(36)$ & $122(32)$ & $59(13)$ & $70(27)$ & $228(69)$ & $156(35)$ & $129(38)$ & 143 & 89 & 115 \\
\hline $\mathrm{TfSat}^{2}, \%$ & $23(14)$ & $32(10)$ & $38(19)$ & $20(5)$ & $23(7)$ & $41(25)$ & $29(6)$ & $30(7)$ & 30 & 14 & 25 \\
\hline $\mathrm{WBC}^{1}$, cells $/ \mathrm{mm}^{3}$ & 6.8 & $4.3^{\circ}$ & 10.2 & 6.2 & 5.3 & 7.7 & 6.8 & 5.9 & 6.65 & 1.8 & 6.5 \\
\hline $\mathrm{TNF}-\alpha^{2}, \mathrm{pg} / \mathrm{ml}$ & $1.41(2.47)$ & $2.26(12.74)$ & $1.07(0.65)$ & $2.62(3.84)$ & $2.53(7.08)$ & $2.74(11.52)$ & $2.86(20.05)$ & $2.82(26.53)$ & 2.38 & 1.43 & 2.11 \\
\hline $\mathrm{IL}-4^{2}, \mathrm{pg} / \mathrm{ml}$ & $0(0)$ & $0.005(0)$ & $0.005(0)$ & $0.0003(0)$ & $0(0)$ & $0.02(0)$ & $0(0)$ & $0(0)$ & 0.001 & 0.002 & 0.0000 \\
\hline
\end{tabular}

$\mathrm{SD}=$ Standard deviation; $\mathrm{BMI}=$ body mass index; $\mathrm{WBC}=$ white blood cell count; TNF- $\alpha=$ tumour necrosis factor- $\alpha$; IL- $4=$ interleukin- 4 . Values in parentheses represent the standard deviation of the arithmetic mean.

${ }^{1}$ Values at baseline evaluation, 1 per subject. ${ }^{2}$ Values for fasting values on up to 7 occasions.

Urine hepcidin-25 was normalized to creatinine concentrations in the same specimen, and relative concentrations were expressed as mega-intensity units per mmol creatinine [(Mint)/ $\mathrm{mmol}$. Concentrations of serum hepcidin-25 were expressed as nM. For urine hepcidin-25 analysis, chip-to-chip variation was $22 \%$ at the high intensity of 48 Mint to $27.5 \%$ at the lower intensity of 20 Mint. For serum hepcidin-25, the intra-run coefficient of variation $(\mathrm{CV})$ was $3.7 \%$ at $7.9 \mathrm{nM}, 2.3 \%$ at $13.4 \mathrm{nM}$ and $2.2 \%$ at $3.1 \mathrm{nM}$. The inter-run CV was $9.1 \%$ at $7.8 \mathrm{nM}$ and $3.9 \%$ at $12.9 \mathrm{nM}$ (all samples, $\mathrm{n}=8$ ).

Assessment of the reliability of hepcidin-25 determination after storage for 24 months at $-20^{\circ} \mathrm{C}$ was based on the disappearance of a number of peaks in the serum mass spectrometry profile around $8,000 \mathrm{~m} / \mathrm{z}$, as observed in sera that remain at $4^{\circ} \mathrm{C}$ for a prolonged period of time ( $>4$ days). The disappearance is likely due to disintegration of some proteins. These samples were scored as questionable and were not included in the line of 'selected samples' in table 2 . The impact of the extended storage period on hepcidin peaks around $2,800 \mathrm{~m} / \mathrm{z}$ was not checked.

Data Handling, Presentation and Statistical Analyses

Results on hepcidin forms from the different collaborating laboratories were initially given in different units. Thus, urinary prohepcidin values were reported in $\mathrm{ng} / \mathrm{l}$ and $\mathrm{ng} / \mathrm{mg}$ of creatinine, respectively. For harmonization of units within the present report, molar values were converted into gravimetric units by multiplying them by the factor of 2.789 (MW of hepcidin-25 in $\mathrm{kDa}$ ) for the serum hepcidin-25 and relating time to creatinine.

Descriptive statistics included the mean, standard deviation and median for all of the variables measured across time in the study. Here, the arithmetic mean was used universally, even for ferritin and cytokines, which are generally expressed as geometric means because of the typical skewed distribution. This was done because of the small sample size and an unfamiliarity of typical distributions of these candidate biomarkers. We used analysis of variance (ANOVA) to compare the averaged hepcidin formats across the 8 participants. As the variables were not always normally distributed, both the Pearson product moment least square and the Spearman rank order correlation coefficients were generated to explore associations between variables in a binary manner.

\section{Results}

Demographic, Haematological and Inflammatory

Characteristics of the Subjects

The demographic, haematological and inflammatory status characteristics of the 8 healthy male volunteers (subjects $\mathrm{A}-\mathrm{H}$ ) are presented in table 1 . The average age of the subjects was $34 \pm 10$ years, and the body mass index varied from 19.4 to 27.4 . Only subject $G$ was in the overweight range, and none was in the underweight domain.

All haemoglobin values were normal, even as adjusted for the altitude of $1,484 \mathrm{~m}$ above sea level of Guatemala City [40]. The individual mean serum ferritin values were all above the iron deficiency threshold, being over 4 times higher than the cut-off point for iron deficiency of 12 $\mu \mathrm{g} / \mathrm{l}$. Similarly, transferrin saturation was in the normal range (16-45\%) [41].

Three indicators relate to ongoing systemic inflammation. The white blood count was marginally elevated above $10,000 \mathrm{~cm}^{3}$ in 1 subject, but remained in the normal range in all other subjects. All mean values for tumour necrosis factor- $\alpha$ were within the normative range $(<20 \mathrm{pg} / \mathrm{ml})$. Undetectable levels of interleukin-4 were found in most samples, with the median being undetectable (zero) in all subjects (normative range $<13 \mathrm{pg} / \mathrm{ml}$ ). With regards to hepcidin being an acute-phase reactant protein $[42,43]$, these values assure that inflammation was not evident in these subjects throughout the course of sampling.

\section{Descriptive Statistics for Hepcidin Forms in the Study Sample}

Table 2 provides the individual and sample descriptive statistics for the 4 formats of hepcidin, i.e. prohepcidin 
Table 2. Normative values for urinary and serum hepcidin forms for 8 adult volunteers (subjects A-H) collected in the fasting state

\begin{tabular}{|c|c|c|c|c|c|c|c|c|c|c|c|}
\hline Variables & A & B & $\mathrm{C}$ & $\mathrm{D}$ & E & F & G & $\mathrm{H}$ & Mean & SD & Median \\
\hline $\begin{array}{l}\text { Urine prohepcidin, } \\
\text { ng/mg creatinine }\end{array}$ & $99.4(42.5)$ & $131.2(67.2)$ & $83.9(31.9)$ & $119.9(38.5)$ & $157.6(53.4)$ & $150.5(100.7)$ & $139.8(44.6)$ & $115.5(33.2)$ & 122.9 & 55.6 & 115.0 \\
\hline $\begin{array}{l}\text { Urine hepcidin- } 25 \mathrm{~T} 0^{1} \text {, mega- } \\
\text { intensity units } / \mathrm{mg} \text { creatinine } \\
\times 10^{-3}\end{array}$ & $8.5(7.7)$ & $21.3(13.5)$ & $13.8(12.4)$ & $3.1(3.1)$ & $7.0(4.8)$ & $18.9(12.0)$ & $4.2(3.8)$ & $9.4(3.8)$ & 10.3 & 9.9 & 7.4 \\
\hline Serum prohepcidin $\mathrm{T} 0^{2}, \mathrm{ng} / \mathrm{ml}$ & $206(66)$ & $222(48)$ & $213(64)$ & $160(51)$ & $220(45)$ & $202(62)$ & $175(66)$ & $162(53)$ & 189 & 60 & 180 \\
\hline Serum hepcidin- $25 \mathrm{~T} 0^{2,3}, \mathrm{ng} / \mathrm{ml}$ & $2.34(0.80)$ & $4.91(1.98)$ & $5.13(4.10)$ & $1.59(0.50)$ & $5.02(4.08)$ & $4.85(1.90)$ & $4.13(1.37)$ & $3.76(2.15)$ & 3.76 & 2.48 & 3.54 \\
\hline $\begin{array}{l}\text { Serum selected hepcidin- } 25 \mathrm{~T}^{4} \text {, } \\
\qquad \mathrm{ng} / \mathrm{ml}\end{array}$ & $5.19(0.84)$ & $6.44(1.28)$ & $6.83(4.85)$ & $1.31(0.56)$ & $4.57(1.62)$ & $5.44(1.14)$ & $4.74(0.81)$ & $4.46(1.48)$ & 4.43 & 2.62 & 4.41 \\
\hline
\end{tabular}

$\mathrm{SD}=$ Standard deviation. Values in parentheses represent the standard deviation of the arithmetic mean.

${ }^{1}$ All values reported represent up to 19 occasions per subject. ${ }^{2}$ Values for fasting values on up to 7 occasions per subject. ${ }^{3}$ Based on all analyses performed. ${ }^{4}$ Based on analyses selected for congruence of concentration value.

and hepcidin-25 each in serum and urine. All data in the urine have been normalized by creatinine to correct for variability in hydration state and urine concentration. The individual subjects' means of prohepcidin in early morning fasting urine samples on the 6 occasions ranged from 83.9 (subject C) to $157.6 \mathrm{ng} / \mathrm{mg}$ creatinine (subject E). There was a 1.9-fold difference between the lowest and highest level. The intra-individual CV, i.e. the standard deviation expressed as a percentage of the mean, for fasting samples ranged from 29 to $67 \%$. The pooled average of all samples analysed across all subjects was $122.9 \pm 55.6$ ng prohepcidin/mg creatinine; the CV was $45 \%$. Table 2 also shows the tabulations for creatinine-normalized urinary hepcidin-25. It shows a range of 3.1-21.3 mega-intensity units/mg creatinine $\times 10^{-3}$, i.e. a 6.8 -fold difference among the means of the subjects. The CVs were in the $40-100 \%$ range. The pooled average was $10.3 \pm 9.9$ megaintensity units $/ \mathrm{mg}$ creatinine $\times 10^{-3}$; the $\mathrm{CV}$ was $>90 \%$.

In the serum, prohepcidin concentrations showed a 1.4fold difference between the low and high individual means of 160 and $222 \mathrm{ng} / \mathrm{ml}$. The CVs ranged from 20 to $38 \%$. The overall mean was $189 \pm 60 \mathrm{ng} / \mathrm{ml}$, with a CV of $32 \%$ (table 2). Due to long storage, concentrations of hepcidin- 25 in serum were analysed in two tiers: (1) all samples irrespective of quality criteria, and (2) the selected samples which conformed to the pre-established quality criterion of not showing disappearance of a number of peaks in the serum mass spectrum around $8,000 \mathrm{~m} / \mathrm{z}$ (table 2). For the selected set of serum hepcidin- 25 concentrations, there was a 5 -fold difference across the individual's pooled, serial values, ranging from $1.31 \pm 0.56 \mathrm{ng} / \mathrm{ml}(\mathrm{CV} 43 \%)$ to $6.83 \pm 4.85 \mathrm{ng} / \mathrm{ml}$ (CV 71\%). The overall mean was 4.43 $\pm 2.62 \mathrm{ng} / \mathrm{ml}$, with a CV of $59 \%$. No subject-to-subject differences of statistical significance at the $5 \%$ level were determined by ANOVA for any of the lines in table 2 .

\section{Associations within and between Prohepcidin and \\ Hepcidin-25 Forms in Serum and Urine}

The approach to evaluating associations among the different hepcidin forms in the same specimen or in the corresponding, alternative biological fluid sample was to conduct both the Pearson product moment least square and Spearman rank order correlation regressions (table 3). Different hepcidin formats, e.g., hepcidin-25 and prohepcidin in the same medium, or hepcidin-25 in serum versus urine and prohepcidin in serum versus urine, showed no significant associations in most cases. An exception was the high correlation between urinary hepcidin-25 with urinary prohepcidin, in which the Pearson correlation coefficient reached statistical significance $(\mathrm{r}=0.432 ; \mathrm{p}=0.001$; table 3$)$. However, there was no significant association between urinary prohepcidin and its homologue in the circulation at concurrent times $(\mathrm{p}=$ 0.833 ; table 3 ). By contrast, statistically significant $r$ values, ranging in magnitude from 0.398 to 0.534 (table 3), were seen for the associations between urinary and serum hepcidin- 25 values.

\section{Association between Underlying Serum Biomarkers}

of Individual Iron Status (Serum Ferritin, Percent

Transferrin Saturation) and Hepcidin Forms Assayed

in Serum and Urine

The next question relates to any potential influence of background iron status on the background set points for 
Table 3. Pearson and Spearman correlation coefficients for the binary associations of all combinations of hepcidin forms in the fasting state

\begin{tabular}{|c|c|c|c|c|}
\hline \multirow[t]{3}{*}{ Binary correlations } & \multicolumn{4}{|c|}{ Zero time values } \\
\hline & \multicolumn{2}{|c|}{ Pearson } & \multicolumn{2}{|c|}{ Spearman } \\
\hline & $\mathrm{r}$ & $\mathrm{p}$ & $\mathrm{r}$ & $\mathrm{p}$ \\
\hline Urinary prohepcidin vs. urinary hepcidin- 25 & 0.432 & 0.001 & 0.136 & 0.332 \\
\hline Serum hepcidin-25 (all) vs. serum prohepcidin & 0.214 & 0.148 & 0.253 & 0.086 \\
\hline Serum hepcidin-25 (selected) vs. serum prohepcidin & 0.081 & 0.678 & 0.186 & 0.333 \\
\hline Serum prohepcidin vs. urinary hepcidin-25 & 0.193 & 0.179 & 0.200 & 0.163 \\
\hline Serum hepcidin-25 (all) vs. urinary hepcidin- 25 & 0.456 & 0.001 & 0.398 & 0.004 \\
\hline Serum hepcidin-25 (selected) vs. urinary hepcidin-25 & 0.534 & 0.002 & 0.430 & 0.016 \\
\hline Serum hepcidin-25 (all) vs. urinary prohepcidin & 0.036 & 0.806 & 0.051 & 0.727 \\
\hline Serum hepcidin-25 (selected) vs. urinary prohepcidin & -0.075 & 0.687 & 0.108 & 0.563 \\
\hline Serum prohepcidin vs. urinary prohepcidin & -0.031 & 0.833 & 0.010 & 0.944 \\
\hline
\end{tabular}

Italicized figures mark significant correlations $(\mathrm{p}<0.05)$.

Table 4. Pearson and Spearman correlation coefficients for two markers of iron status (mean of all ferritin measurements, mean of fasting \%TfSat) with all-study means for the various serum and urinary hepcidin forms ( $\mathrm{n}=8$ per correlation)

\begin{tabular}{|c|c|c|c|c|c|c|c|c|}
\hline \multirow[t]{3}{*}{ Hepcidin variables } & \multicolumn{4}{|c|}{ Ferritin (all times, pooled) } & \multicolumn{4}{|c|}{ \%TfSat (zero times) } \\
\hline & \multicolumn{2}{|c|}{ Pearson } & \multicolumn{2}{|c|}{ Spearman } & \multicolumn{2}{|c|}{ Pearson } & \multicolumn{2}{|c|}{ Spearman } \\
\hline & $\mathrm{r}$ & $\mathrm{p}$ & $\mathrm{r}$ & $\mathrm{p}$ & $\mathrm{r}$ & $\mathrm{p}$ & $\mathrm{r}$ & $\mathrm{p}$ \\
\hline Urinary prohepcidin & -0.157 & 0.710 & -0.500 & 0.207 & -0.078 & 0.854 & -0.108 & 0.799 \\
\hline Urinary hepcidin-25 & 0.661 & 0.075 & 0.405 & 0.320 & 0.626 & 0.097 & 0.503 & 0.204 \\
\hline Serum prohepcidin & 0.468 & 0.243 & 0.405 & 0.320 & -0.412 & 0.311 & -0.333 & 0.420 \\
\hline Serum hepcidin-25 (all) & 0.921 & 0.009 & 0.810 & 0.015 & 0.831 & 0.011 & 0.690 & 0.058 \\
\hline Serum hepcidin-25 (selected) & 0.921 & 0.009 & 0.829 & 0.042 & 0.710 & 0.049 & 0.524 & 0.183 \\
\hline
\end{tabular}

Italicized figures mark significant correlations $(\mathrm{p}<0.05)$.

hepcidin in circulation and in urine (table 4). For serum hepcidin-25, significant correlations were seen whether using the selected samples or all measurements. Approaching statistical significance, with a Pearson $r$ value of 0.661 ( $p=0.075)$, was the association of fasting urinary hepcidin-25 with the pooled ferritin value for an individual (table 4). Serum hepcidin-25 correlated significantly with serum ferritin (table 4 ).

The degree of saturation of serum transferrin has long been used as a clinical marker of iron availability even before ferritin assays became available in the 1970s [41]. While ferritin has intrinsically high within-individual stability, the diurnal fluctuations in serum iron are well known. Therefore, only the fasting percent transferrin saturation (\%TfSat) status is given here, reflecting the iron status of the subjects. Thus, this variable was subjected to correlation coefficient analysis (table 4). The pattern of significant and near-significant associations for fasting \%TfSat with hepcidin forms virtually mimicked those with ferritin (table 4).

\section{Discussion}

Over the past years, interest has emerged around hepcidin, a hormone of hepatic origin, which is of central importance for the control of iron absorption and maintenance of body iron homeostasis $[9,43,44]$. The capac- 
ity for assaying the chemical forms of hepcidin in various biological fluids is still in its infancy, though meanwhile, serum hepcidin- 25 values in control populations are available for reference $[14,20]$, and assays worldwide were compared in a first round robin [45]. While reports on detection and quantification of prohepcidin, hepcidin-25, or both, in human urine proliferated [e.g., see ref. 7, 2639 ], assays related to circulating hepcidin- 25 were less common before corresponding serum assays had been developed [13, 15-24].

\section{Strengths and Limitations of the Available Hepcidin Data Set}

The major strength of the present study is the simultaneous measurement of all 4 formats of hepcidin concurrently in the same individual; this allows for all possible combinations of simultaneous inter-comparison. Two obvious limitations of this study relate to sample size and specimen stability. The present trial was primarily designed as a metabolic study, and the 8 individuals may not be representative of the general population for men, not even for healthy males in Guatemala. Moreover, given the well-established differences in iron status between men and women [46], hepcidin status may differ between the sexes; the absence of any female participants leaves extrapolation across sex in abeyance. At the time of designing and executing the present study in 2005 , an assay for serum hepcidin-25 did not exist within our collaboration network; it only became available as of 2007 [13]. Thus, serum aliquots used for the hepcidin-25 assay underwent 2 years of storage at $-20^{\circ} \mathrm{C}$, whereas assays of the urine for both prohepcidin and hepcidin-25 and of serum for prohepcidin were performed in 2005. On the one hand, this leads to a dilemma of inter-variable consistency and data interpretation. On the other hand, observation of only small differences between hepcidin- 25 values analysed in all collected samples as compared to those that certified by internal quality standards as well as the extent of agreement between these two sets (table 2) suggest a comparably high stability of serum hepcidin-25. The presented data obtained in fasting morning samples of serum and urine and their correlation among each other should begin to contribute to a familiarity with what normative concentrations in healthy adult men in an urban setting in a tropical nation might be. The caveat for the utility of the present data as reference values, of course, is the limited number of subjects.
Comparison and Inter-Correlations of the 4 Hepcidin

Forms

The primary purpose of this publication was a focus on the association among the 4 different forms of hepcidin that can now be quantified in clinical chemistry. In agreement with the conclusion by Roe et al. [11] and Kemna et al. [47], which discarded any biological utility from assaying serum prohepcidin, we confirm a lack of association of this format with other hepcidin forms.

In the context of mutual regulation of iron status and hepcidin-25 synthesis, the 1-2 orders of magnitude (i.e. 10-100 fold) greater concentration of prohepcidin compared to hepcidin-25 in serum (table 2) is consistent with how a precursor and an active derivative might be related to one another. The significant association between serum and urinary hepcidin- 25 concentrations is in agreement with this format being filtered by the glomerulus and being $95-100 \%$ reabsorbed by the proximal tubulus $[14,20]$. In contrast, the lacking correlation between prohepcidin and both serum and urine hepcidin- 25 raises questions about the true identity and possible regulatory role of prohepcidin.

\section{Relationship between the 4 Hepcidin Formats and the Subjects' Iron Status}

Serum hepcidin and serum prohepcidin did not correlate in earlier trials [47], while hepcidin-25 in urine and serum did $[14,20]$. Because of the totally non-invasive collection format for urine specimens, urinary biomarkers, when reliable and useful, are ideal for population surveys. Blood drawing is inconvenient due to cultural factors and carries the risk to transmit blood-borne diseases. In particular for iron status assessment in the context of targeted iron supplementation to iron-deficient children in malaria-endemic areas, it would be useful to have a reliable urinary marker [48]. Tempting as it would be to anticipate a non-invasive biomarker for iron status in the measurement of urinary hepcidin-25, the observed within-subject instability militates against its ever serving alone as a reliable screening value for individual iron status [49]. However, for the assessment of large groups, averaged values of urinary concentrations of the active hormone could yield discriminations among iron-replete and iron-depleted populations, which would be of major importance in field studies (table 4) and needs further investigation.

With the aforementioned caveats on storage time and the limited number of volunteers in mind, issues of variance and stability within assays can be informative. When fasting hepcidin values for all 4 formats were aver- 
aged within individuals, coefficients of variations were relatively large over the observation period of 9 weeks (table 2). Inter-individual ANOVA comparisons failed to find any significant differences between the 8 individuals for any of the hepcidin formats under these conditions. However, fasting hepcidin- 25 of both iron statuses, either low or high, showed an appropriate reciprocal association of hepcidin-25 with classical markers of iron status in earlier trials $[14,20,50]$. Accordingly, a concept of hepcidin individuality would seem to be supported by the array of positive associations found between the baseline hepcidin- 25 concentrations in serum (and the trends in urine) and the two indicators of human iron status - ferritin and \%TfSat (table 4) - which is in accordance with findings by Kroot et al. [49]. Thus, serum values of hepcidin-25 may have a potential as iron status indicator. However, this is more promising on the collective group basis, as the large intra-individual standard deviations observed over time seem to call for repeated hepcidin- 25 determinations in individuals to develop a stable estimate. Serum and urinary prohepcidin, by contrast, correlated much less well with iron status, showing no promise as iron status indicators in our data set (table 4).

\section{Comparison of Our Findings with Those of Other \\ Investigations}

Recently, Ganz and collaborators [20] have explored some of the same associations between serum and urinary hepcidin-25. In this regard, they reported a correlation coefficient of 0.82 for serum versus urine, also with adjustment for creatinine, whereas we found an $r$ value of 0.46 with an analogous Pearson regression. Our correlation coefficient of $r=0.92$ compares favourably with and confirms the $r=0.63$ association observed in the Pearson regression of circulating ferritin with serum hepcidin-25 in the recent report by Ganz et al. [20] and with $r=0.68$ reported by Swinkels et al. [14].

\section{Conclusions}

The findings from repeated measurements of the putative precursor and the hormonally active forms of hepcidin in a limited number of healthy males provide some initial descriptive data and indications of interactions among the different forms. As a circulating hormone, both hepcidin moieties emulate the nature of other known hormones. Moreover, the significant association between hepcidin-25 in serum, and the weak correlation of hepcidin-25 in urine with the iron status indicators determined in parallel, suggest a certain promise of these variables as iron status markers. By contrast, no similar association was found for prohepcidin formats. Now that assays for two forms of the hepcidin hormone have debuted for multiple biological fluids in clinical chemistry, the way is cleared to further address the biological and interactive questions set forth in this analysis.

\section{Acknowledgements}

Hildegard Grunow Foundation of Munich supported the project. Licda Isabel Masanet de Ramirez kindly performed the haematological testing of the subjects. We thank Dr. Brenda Barahona and Mr. Carlos Tanchez for their assistance in the recruitment of subjects and the collection and processing of biological samples.

\section{References}

1 Pigeon C, Ilyin G, Courselaud B, Leroyer P, Turlin B, Brissot P, Loreal O: A new mouse liver-specific gene, encoding a protein homologous to human antimicrobial peptide hepcidin, is overexpressed during iron overload. J Biol Chem 2001;276:7811-7819.

$\checkmark 2$ Park CH, Valore EV, Waring AJ, Ganz T: Hepcidin, a urinary antimicrobial peptide synthesized in the liver. J Biol Chem 2001; 276:7806-7810.

-3 Nicolas G, Bennoun M, Devaux I, Beaumont C, Grandchamp B, Kahn A, Vaulont S: Lack of hepcidin gene expression and severe tissue iron overload in upstream stimulatory factor 2 (USF2) knockout mice. Proc Natl Acad Sci USA 2001;98:8780-8785.

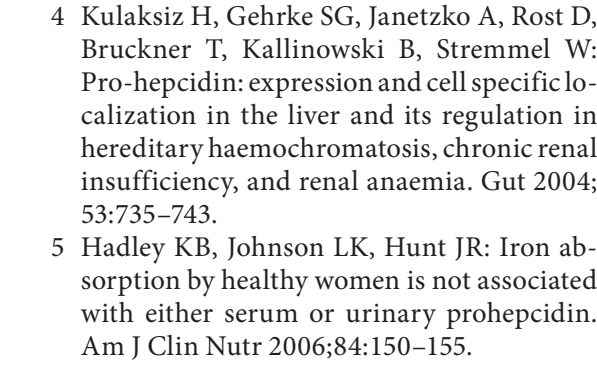

6 Christiansen H, Saile B, Hermann RM, Rave-Fränk M, Hille A, Schmidberger $H$, Hess CF, Ramadori G: Increase of hepcidin plasma and urine levels is associated with acute proctitis and changes in hemoglobin levels in primary radiotherapy for prostate cancer. J Cancer Res Clin Oncol 2007;133: 297-304.

7 Kemna E, Pickkers P, Nemeth E, van der Hoeven H, Swinkels D: Time-course analysis of hepcidin, serum iron, and plasma cytokine levels in humans injected with LPS. Blood 2005;106:1864-1866. 
8 Theurl I, Mattle V, Seifert M, Mariani M, Marth C, Weiss G: Dysregulated monocyte iron homeostasis and erythropoietin formation in patients with anemia of chronic disease. Blood 2006;107:4142-4148.

-9 Ganz T: Hepcidin - a regulator of intestinal iron absorption and iron recycling by macrophages. Best Pract Res Clin Haematol 2005; 18:171-182.

-10 Taes YE, Wuyts B, Boelaert JR, De Vriese AS, Delanghe JR: Prohepcidin accumulates in renal insufficiency. Clin Chem Lab Med 2004;42:387-389.

-11 Roe MA, Spinks C, Heath AL, Foxall R, Wimperis J, Wolf C, Fairweather-Tait SJ: Serum prohepcidin concentrations: no association with iron absorption in healthy men; and no relationship with iron status in men carrying HFE mutations, hereditary haemochromatosis patients undergoing phlebotomy treatment, or pregnant women. Br J Nutr 2007;97:544-549.

12 Valore EV, Ganz T: Posttranslational processing of hepcidin in human hepatocytes is mediated by the prohormone convertase furin. Blood Cell Mol Dis 2008;40:139-140.

-13 Kemna EH, Tjalsma H, Podust VN, Swinkels DW: Mass spectrometry-based hepcidin measurements in serum and urine: analytical aspects and clinical implications. Clin Chem 2007;53:620-628.

-14 Swinkels DW, Girelli D, Laarakkers C, Kroot J, Campostrini N, Kemna EH, Tjalsma H: Advances in quantitative hepcidin measurements by time-of-flight mass spectrometry. PLoS One 2008;3:e2706.

-15 Tomosugi N, Kawabata H, Wakatabe R, Higuchi $\mathrm{M}$, Yamaya $\mathrm{H}$, Umehara $\mathrm{H}$, Ishikawa I: Detection of serum hepcidin in renal failure and inflammation by using protein chip system. Blood 2006;108:1381-1387.

-16 Murphy AT, Witcher DR, Luan P, Wroblewski VJ: Quantitation of hepcidin from human and mouse serum using liquid chromatography tandem mass spectrometry. Blood 2007;110:1048-1054.

-17 Theurl I, Aigner E, Theurl M, Nairz M, Seifert M, Schroll A, Sonnweber T, Eberwein L, Witcher DR, Murphy AT, Wroblewski VJ, Wurz E, Datz C, Weiss G: Regulation of iron homeostasis in anemia of chronic disease and iron deficiency anemia: diagnostic and therapeutic implications. Blood 2009;113: 5277-5286.

- 18 Koliaraki V, Marinou M, Vassilakopoulos TP, Vavourakis E, Tsochatzis E, Pangalis GA, Papatheodoridis G, Stamoulakatou A, Swinkels DW, Papanikolaou G, Mamalaki A: A novel immunological assay for hepcidin quantification in human serum. PLoS One 2009;4:e4581.
9 de Mast Q, van Dongen-Lases EC, Swinkels DW, Nieman AE, Roestenberg M, Druilhe P, Arens TA, Luty AJ, Hermsen CC, Sauerwein RW, van der Ven AJ: Mild increases in serum hepcidin and interleukin- 6 concentrations impair iron incorporation in haemoglobin during an experimental human malaria infection. Br J Haematol 2009; 145:657-664.

20 Ganz T, Olbina G, Girelli D, Nemeth E, Westermann M: Immunoassay for human serum hepcidin. Blood 2008;112:4292-4297.

21 Grebenchtchikov N, Geurts-Moespot AJ, Kroot JJ, den Heijer M, Tjalsma H, Swinkels DW, Sweep FG: High-sensitive radioimmunoassay for human serum hepcidin. $\mathrm{Br}$ J Haematol 2009;146:317-325.

22 Ashby DR, Gale DP, Busbridge M, Murphy KG, Duncan ND, Cairns TD, Taube DH, Bloom SR, Tam FW, Chapman RS, Maxwell $\mathrm{PH}$, Choi P: Plasma hepcidin levels are elevated but responsive to erythropoietin therapy in renal disease. Kidney Int 2009;75: 976-981.

23 Li H, Rose MJ, Tran L, Zhang J, Miranda LP, James CA, Sasu BJ: Development of a method for the sensitive and quantitative determination of hepcidin in human serum using LCMS/MS. J Pharmacol Toxicol Methods 2009; 59:171-180.

24 Murao N, Ishigai M, Yasuno H, Shimonaka Y, Aso Y: Simple and sensitive quantification of bioactive peptides in biological matrices using liquid chromatography/selected reaction monitoring mass spectrometry coupled with trichloroacetic acid clean-up. Rapid Commun Mass Spectrom 2007;21:40334038.

25 Weiss G, Theurl I, Eder S, Koppelstaedter C, Kurz K, Sonnweber T, Kobold U, Mayer G Serum hepcidin concentration in chronic haemodialysis patients: associations and effects of dialysis, iron and erythropietin therapy. Eur J Clin Invest 2009;39:883-890.

26 Nemeth E, Roetto A, Garozzo G, Ganz T, Camaschella C: Hepcidin is decreased in TFR2 hemochromatosis. Blood 2005;105 1803-1806.

27 Papanikolaou G, Samuels ME, Ludwig EH, MacDonald ML, Franchini PL, Dubé MP, Andres L, MacFarlane J, Sakellaropoulos N, Politou M, Nemeth E, Thompson J, Risler JK Zaborowska C, Babakaiff R, Radomski CC, Pape TD, Davidas O, Christakis J, Brissot P, Lockitch G, Ganz T, Hayden MR, Goldberg YP: Mutations in HFE2 cause iron overload in chromosome 1q-linked juvenile hemochromatosis. Nat Genet 2004;36:77-82.

28 Détivaud L, Nemeth E, Boudjema K, Turlin B, Troadec MB, Leroyer P, Ropert M, Jacquelinet S, Courselaud B, Ganz T, Brissot P, Loréal O: Hepcidin levels in humans are correlated with hepatic iron stores, hemoglobin levels, and hepatic function. Blood 2005;106: 746-748.
29 Papanikolaou G, Tzilianos M, Christakis JI, Bogdanos D, Tsimirika K, MacFarlane J, Goldberg YP, Sakellaropoulos N, Ganz T, Nemeth E: Hepcidin in iron overload disorders. Blood 2005;105:4103-4105.

-30 Kattamis A, Papassotiriou I, Palaiologou D, Apostolakou F, Galani A, Ladis V, Sakellaropoulos N, Papanikolaou G: The effects of erythropoetic activity and iron burden on hepcidin expression in patients with thalassemia major. Haematologica 2006;91:809812 .

31 Kearney SL, Nemeth E, Neufeld EJ, Thapa D, Ganz T, Weinstein DA, Cunningham MJ: Urinary hepcidin in congenital chronic anemias. Pediatr Blood Cancer 2007;48:57-63.

32 Howard CT, McKakpo US, Quakyi IA, Bosompem KM, Addison EA, Sun K, Sullivan D, Semba RD: Relationship of hepcidin with parasitemia and anemia among patients with uncomplicated Plasmodium falciparum malaria in Ghana. Am J Trop Med Hyg 2007; 77:623-626.

-33 Trombini P, Coliva T, Nemeth E, Mariani R, Ganz T, Biondi A, Piperno A: Effects of plasma transfusion on hepcidin production in human congenital hypotransferrinemia. Haematologica 2007;92:1407-1410.

34 Piperno A, Girelli D, Nemeth E, Trombini P, Bozzini C, Poggiali E, Phung Y, Ganz T, Camaschella C: Blunted hepcidin response to oral iron challenge in HFE-related hemochromatosis. Blood 2007;110:4096-4100.

>35 Origa R, Galanello R, Ganz T, Giagu N, Maccioni L, Faa G, Nemeth E: Liver iron concentrations and urinary hepcidin in beta-thalassemia. Haematologica 2007;92:583-588.

36 Bozzini C, Campostrini N, Trombini P, Nemeth E, Castagna A, Tenuti I, Corrocher R, Camaschella C, Ganz T, Olivieri O, Piperno A, Girelli D: Measurement of urinary hepcidin levels by SELDI-TOF-MS in HFE-hemochromatosis. Blood Cells Mol Dis 2007;40: 347-352.

37 Cherian S, Forbes DA, Cook AG, Sanfilippo FM, Kemna EH, Swinkels DW, Burgner DP: An insight into the relationships between hepcidin, anemia, infections and inflammatory cytokines in pediatric refugees: a crosssectional study. PLoS One 2008;3:e4030.

-38 de Mast Q, Nadjm B, Reyburn H, Kemna EH, Amos B, Laarakkers CM, Silalye S, Verhoef $\mathrm{H}$, Sauerwein RW, Swinkels DW, van der Ven AJ: Assessment of urinary concentrations of hepcidin provides novel insight into disturbances in iron homeostasis during malarial infection. J Infect Dis 2009;199:253-262.

-39 Bansal SS, Halket JM, Fusova J, Bomford A, Simpson RJ, Vasavda N, Thein SL, Hider RC: Quantification of hepcidin using matrix-assisted laser desorption/ionization time-offlight mass spectrometry. Rapid Commun Mass Spectrom 2009;23:1531-1542. 
-40 Dirren H, Logman HGM, Barlay CV, Freire WB: Altitude correction for haemoglobin. Eur J Clin Nutr 1994;48:625-632.

-41 Cook JD, Finch CA: Assessing iron status of a population. Am J Clin Nutr 1979;32:21152119.

42 Nemeth E, Valore EV, Territo M, Schiller G, Lichtenstein A, Ganz T: Hepcidin, a putative mediator of anemia of inflammation, is a type II acute-phase protein. Blood 2003;101: 2461-2463.

-43 Nicolas G, Chauvet C, Viatte L, Danan JL, Bigard X, Devaux I, Beaumont C, Kahn A, Vaulont S: The gene encoding the iron regulatory peptide hepcidin is regulated by anemia, hypoxia, and inflammation. J Clin Invest 2002;110:1037-1044.
44 Kemna EH, Tjalsma H, Willems HL, Swinkels DW: Hepcidin: from discovery to differential diagnosis. Haematologica 2008;93: 90-97.

45 Kroot JJ, Kemna EH, Bansal SS, Busbridge M, Campostrini N, Girelli D, Hider RC, Koliaraki V, Mamalaki A, Olbina G, Tomosugi N, Tselepis C, Ward DG, Ganz T, Hendriks JC, Swinkels DW: Results of the first international round robin for the quantification of urinary and plasma hepcidin assays: need for standardization. Haematologica 2009;94: 1748-1752.

46 Yip R: Iron; in Bowman BA, Russell RM (eds): Present Knowledge in Nutrition, ed 8. Washington, ILSI Press, 2001, pp 311-351.

-47 Kemna EH, Kartikasari AE, van Tits LJ, Pickkers P, Tjalsma H, Swinkels DW: Regulation of hepcidin: insights from biochemical analyses on human serum samples. Blood Cells Mol Dis 2008;40:339-346.
48 Schümann K, Solomons NW: Safety of interventions to reduce nutritional anemias; in Kraemer K, Zimmermann MB (eds): Nutritional Anemia. Basel, Sight and Life Press, 2007, pp 285-314.

49 Kroot J, Hendriks JC, Laarakkers CM, Klaver SM, Kemna EH, Tjalsma H, Swinkels DW: (Pre)analytical imprecision, betweensubject variability, and daily variations in serum and urine hepcidin: implications for clinical studies. Anal Biochem 2009;389: 124-129.

50 Peeling P, Dawson B, Goodman C, Landers G, Trinder D: Athletic induced iron deficiency: new insights into the role of inflammation, cytokines and hormones. Eur J Appl Physiol 2008;103:381-391. 